\title{
Perkembangan Politik Hukum Pemerintahan Desa Menurut Undang-Undang \\ Nomor 32 Tahun 2004 tentang Pemerintahan Daerah dan Undang-Undang Nomor 6 Tahun 2014 tentang Desa
}

\author{
Agus Kusnadi*
}

\begin{abstract}
Abstrak
Desa merupakan bentuk pemerintahan lokal yang sudah terbentuk dari masyarakat adat yang sudah ada sebelum berdirinya negara Republik Indonesia. Pemerintahan lokal tersebut terdiri dari sistem nilai dan lembaga pemerintahan yang tumbuh dan berkembang yang diwariskan secara turun-temurun. Setelah Indonesia merdeka, desa menjadi salah satu unsur pemerintahan formal dalam sistem desentralisasi. Terdapat beberapa undangundang yang mengatur mengenai pemerintahan desa yang diantaranya adalah UndangUndang Nomor 5 Tahun 1979 tentang Pemerintahan Desa yang menempatkan desa sebagai daerah administratif di bawah kecamatan. Setelah itu, pemerintahan desa menjadi bagian dari pemerintahan daerah dan diatur di dalam undang-undang pemerintahan daerah, baik dalam Undang-Undang Nomor 22 Tahun 1999 maupun Undang-Undang Nomor 32 Tahun 2004 tentang Pemerintahan Daerah. Pada tahun 2014, pengaturan tentang desa kembali dipisahkan dari pengaturan pemerintahan daerah melalui Undang-Undang Nomor 6 Tahun 2014 tentang Desa. Berdasarkan uraian di atas, menjadi penting untuk dapat mengkaji arah perkembangan politik hukum pemerintahan desa, setidaknya berdasarkan Undang-Undang Nomor 32 Tahun 2004 tentang Pemerintahan Daerah dan Undang-Undang Nomor 6 Tahun 2014 tentang Desa.
\end{abstract}

Kata kunci: Desa, desentralisasi, otonomi, pemerintahan desa, politik hukum.

\section{The Development of Village Governance Legal Policy According to Law Number 23 of 2004 Concerning Local Government and Law Number 6 of 2014 Concerning Village}

\begin{abstract}
The village is a form of local government that has been formed from the indigenous communities that existed before Republic of Indonesia was found. The local government consists of a value system and government bodies that grow and develop that inherited from generation to generation. After Indonesian independence, the village became one of the elements of formal governance within a decentralized system. There are several laws regulating the village administration of which is Law Number 5 of 1979 on Village Government which places the village as the area under the administrative districts. After that, the village government to be part of the local government and regulated in the laws of local government, both in Law Number 22 of 1999 and Law Number 32 of 2004 on Local
\end{abstract}

PADJADJARAN Jurnal IImu Hukum Volume 2 Nomor 3 Tahun 2015 [ISSN 2460-1543] [e-ISSN 2442-9325]

* Dosen Hukum Tata Negara Fakultas Hukum Universitas Padjadjaran, Jl. Dipatiukur No.35 Bandung, aguskusnadi1117@gmail.com, S.H.,M.H.,Dr. (Universitas Padjadjaran). 
Government. In 2014, the re-setting of the village is separated from regulation of local government through Law Number 6 of 2014 on Village. Based on the illustration above, it becomes important to assess the direction and development of village governance law legal policy, at least based on Law Number 32 Year 2004 on Local Government and Law Number 6 of 2014 on Village.

Keywords: Village, decentralization, autonomy, legal policy, village governance.

\section{A. Pendahuluan}

"Kelima anasir demokrasi asli itu: rapat, mufakat, gotong-royong, hak mengadakan protes bersama dan hak menyingkir dari daerah kekuasaan raja, dipuja dalam lingkungan pergerakan nasional sebagai pokok yang kuat bagi demokrasi sosial, yang akan dijadikan dasar pemerintahan Indonesia merdeka di masa mendatang. Tidak semua dari yang tampak bagus pada demokrasi desa dapat dipakai pada tingkat yang lebih tinggi dan modern. Tetapi sebagai dasar, ia dipandang terpakai. Betapapun juga, orang tidak mau melepaskan cita-cita demokrasi sosial, yang banyak sedikitnya bersendi kepada organisasi sosial di dalam masyarakat asli sendiri". ' (Moh. Hatta).

Pandangan Mohammad Hatta di atas mencerminkan bagaimana tata nilai yang hidup pada masyarakat asli Indonesia yang telah lama hidup dan menjadi inspirasi didirikannya Negara Republik Indonesia. Organisasi sosial di dalam masyarakat asli sendiri sebagaimana dikemukakan oleh Hatta di atas merujuk pada pengertian desa yang mampu mengatur dirinya sendiri berdasarkan adat istiadatnya. Artinya hakikat desa adalah entitas pemerintahan asli yang otonom yang juga dapat memangku kepentingannya sendiri. Di sisi lain, dalam kerangka negara kesatuan, negara memiliki kepentingan terhadap desa yang pada akhirnya melahirkan intervensi negara terhadap desa. ${ }^{2}$

Secara historis, intervensi negara terhadap tatanan pemerintahan desa telah terjadi semenjak masa kolonial Hindia-Belanda dengan diberlakukannya Inlandse Gementee Ordonantie (IGO). ${ }^{3}$ Ordonansi tersebut merupakan pelaksana dari ketentuan Regering Reglemen (RR) yang memberikan pengakuan kepada desa sebagai kesatuan masyarakat yang berbadan hukum. ${ }^{4}$ Oleh karena itu, pada rezim ini desa dikukuhkan sebagai sebuah entitas yang otonom untuk dapat mengurus urusan rumah tangganya sendiri serta dapat mengangkat kepala dan perangkat

1 Yudi Latif, Negara Paripurna, Jakarta: Gramedia Pustaka Utama, 2011, hlm. 389.

2 Rega Felix, "Kedudukan Perangkat Desa Dalam Sistem Pemerintahan Desa di Indonesia”, Skripsi Fakultas Hukum Universitas Padjadjaran, 2013, hlm. 2.

3 Soetardjo Kartohadikoesoemo, Desa, Yogyakarta: Sumur Bandung, 1953, hlm. 180.

4 Bayu Surianingrat, Pemerintahan Administrasi Desa dan Kelurahan, Jakarta: Rineka Cipta, 1992, hlm. 70. 
desa berdasarkan adat kebiasaan setempat. ${ }^{5}$

Setelah Indonesia merdeka, kedudukan desa sebagai entitas yang otonom tetap dipertahankan. Hal ini dapat terlihat dengan meletakkan kedudukan desa sebagai daerah tingkat III berdasarkan Undang-Undang Nomor 22 Tahun 1948 tentang Penetapan Aturan-Aturan Pokok Mengenai Pemerintahan Sendiri di Daerah-Daerah yang Berhak Mengatur dan Mengurus Rumah Tangganya Sendiri. Politik hukum pemerintahan desa sebagai daerah tingkat III semakin diperkuat oleh pemerintah dengan menerbitkan Undang-Undang Nomor 19 Tahun 1965 tentang Desapraja Sebagai Bentuk Peralihan Untuk Mempercepat Terwujudnya Daerah Tingkat III di Seluruh Wilayah Republik Indonesia (UU Desapraja). UU Desapraja tersebut ditujukan untuk mempercepat proses transformasi desa-desa menjadi desapraja sebelum berubah menjadi daerah tingkat III. Meskipun begitu, politik hukum untuk menempatkan desa sebagai daerah tingkat III tidak pernah terwujud. ${ }^{6}$

Pada masa orde baru, kedudukan desa dalam struktur ketatanegaraan Indonesia mengalami perubahan yang signifikan. Pada masa ini, desa tidak lagi diposisikan sebagai sebuah entitas yang otonom, melainkan hanya diberikan status sebagai organ administrasi pemerintah di bawah kecamatan yang merupakan perangkat pemerintah pusat di daerah berdasarkan Undang-Undang Nomor 5 Tahun 1979 tentang Pemerintahan Desa (UU Pemerintahan Desa). ${ }^{7}$ Berdasarkan konsiderans UU Pemerintahan Desa tersebut dapat terlihat bahwa politik hukum pemerintahan desa pada saat itu adalah penyeragaman desa di Indonesia. Kondisi tersebut mengakibatkan struktur tatanan asli desa yang didasarkan pada adat istiadat setempat menjadi runtuh. ${ }^{8}$

Pada masa reformasi, terjadi perubahan arah politik hukum pemerintahan desa dari yang sebelumnya bersifat penyeragaman menjadi pengakuan atas keberagaman struktur tatanan desa yang tumbuh berdasarkan adat istiadat setempat. ${ }^{9}$ Politik hukum pemerintahan desa ini tidak berubah meskipun pada

5 Otonomi desa untuk mengurus urusan rumah tangganya sendiri ini dinyatakan dalam Pasal 71 RR dan Pasal 128 ayat (3) IS. Sementara itu, kewenangan untuk dapat memilih kepala desa berdasarkan adat istiadat setempat diatur dalam staatsblad Tahun 1907 Nomor 212.

6 Rega Felix dalam skripsinya menyatakan bahwa tidak terwujudnya politik hukum untuk menempatkan desa sebagai daerah tingkat III dikarenakan situasi sosial-politik yang tidak mendukung pada saat itu. Dapat dilihat pada Rega Felix, Op.cit., hlm. 4.

7 Pasal 1 huruf a Undang-Undang Nomor 5 Tahun 1979 tentang Pemerintahan Desa (UU Pemerintahan Desa): "Desa adalah kesatuan masyarakat hukum yang mempunyai organisasi pemerintahan terendah langsung di bawah camat".

8 Seperti pada masa berlakunya (UU Pemerintahan Desa), kepala desa dipilih langsung oleh warga desa, tetapi undang-undang tidak memberikan ruang apapun bagi warga untuk dapat mengawasi kinerja dari kepala desa. Pengawasan terhadap kepala desa diberikan secara mutlak kepada pemerintah atasan desa dalam bentuk kewenangan untuk mengangkat dan memberhentikan kepala desa, sehinga kepala desa hanya akan tunduk pada kehendak pemerintah atasan desa. Dapat dilihat Pasal 6, Pasal 15, dan Pasal 16 (UU Pemerintahan Desa).

9 Pengakuan akan keberagaman desa terlihat dalam pengertian tentang desa pada Undang-Undang Nomor 22 Tahun 1999 tentang Pemerintahan Daerah (UU Pemda 1999) yang menyatakan: “Desa atau yang disebut dengan 
tahun 2004 melalui Undang-Undang Nomor 32 Tahun 2004 tentang Pemerintahan Daerah (UU Pemda 2004) terbit menggantikan Undang-Undang Nomor 22 Tahun 1999 tentang Pemerintahan Daerah (UU Pemda 1999). Namun demikian, terdapat kerancuan dalam penentuan status perangkat daerah, yakni jabatan sekretaris desa diberikan status sebagai pegawai negeri sipil (PNS) tanpa diikuti oleh perangkat desa lainnya termasuk kepala desa. Oleh karena itu, pada masa UU Pemda 2004 ini terdapat gejolak yang timbul di masyarakat desa untuk turut mengangkat perangkat desa lainnya, terutama kepala desa, untuk turut diberikan status sebagai PNS. ${ }^{10}$

Setelah rezim UU Pemda 2004 yang menempatkan pengaturan tentang pemerintahan desa sebagai bagian dari pemerintahan daerah, pada tahun 2014 disahkan Undang-Undang Nomor 6 Tahun 2014 tentang Desa (UU Desa) yang mengatur pemerintahan desa secara tersendiri. Beberapa kebijakan hukum baru yang terlihat berdasarkan undang-undang tersebut adalah adanya alokasi dana untuk desa yang langsung berasal dari anggaran pendapatan dan belanja negara (APBN). Hal ini menjadikan sumber-sumber pendanaan desa menjadi lebih banyak dari sebelumnya. Penambahan sumber pendanaan ini secara kasat mata memperlihatkan adanya politik hukum untuk mempertahankan eksistensi desa sebagai entitas yang otonom. Namun, perlu untuk dikaji apakah UU Desa tersebut mengalami perubahan politik hukum yang signifikan dari undang-undang pendahulunya. Selain itu, artikel ini juga akan mengkaji apakah UU Desa telah mengakomodasi kebutuhan hukum yang dirasakan pada masa berlakunya UU Pemda 2004. Pembahasan dua permasalahan yang mendasar ini diperlukan untuk dapat memahami arah perkembangan politik hukum pemerintahan desa dari UU Pemda 2004 ke UU Desa, serta perubahan karakter dan kedudukan desa yang sebelumnya merupakan bagian dari pemerintahan daerah.

\section{B. Perkembangan Politik Hukum Pemerintahan Desa dari Undang-Undang Nomor 32 Tahun 2004 tentang Pemerintahan Daerah ke Undang-Undang Nomor 6 Tahun 2014 tentang Desa}

Pada bagian ini akan diuraikan perkembangan politik hukum pemerintahan desa berdasarkan UU Pemda 2004 ke UU Desa. Pada bagian awal, politik hukum pemerintahan desa menurut UU Pemda 2004 akan terlebih dahulu diuraikan. Setelah itu akan dilanjutkan dengan memaparkan mengenai politik hukum pemerintahan desa menurut UU Desa yang akan difokuskan pada bagian yang berubah secara signifikan dari undang-undang pendahulunya.

nama lain, selanjutnya disebut desa, adalah kesatuan masyarakat hukum yang memiliki kewenangan untuk mengatur dan mengurus kepentingan masyarakat setempat berdasarkan asal-usul dan adat istiadat setempat yang diakui dalam sistem pemerintahan nasional dan berada di daerah Kabupaten".

10 Koran Sindo, "Perangkat Desa Kembali Tuntut Dijadikan PNS", diakses 4 Juni 2015. 
Sementara itu, politik hukum yang dimaksud dalam tulisan ini mengacu pada terminologi politik hukum yang diutarakan oleh Imam Syaukani sebagai sebuah kebijakan di bidang hukum. ${ }^{11}$ Terminologi tersebut merupakan bentukan dari dua kata, yakni recht (hukum) dan politiek (beleid/kebijakan). ${ }^{12}$ Mengutip apa yang dikemukakan oleh T.M. Radhie tentang makna politik hukum, bahwa politik hukum merupakan suatu pernyataan kehendak penguasa negara mengenai hukum yang berlaku di wilayahnya dan mengenai arah perkembangan hukum yang dibangun. ${ }^{13}$ Berdasarkan pendekatan pada definisi politik hukum tersebutlah tulisan ini akan mencoba melihat arah perkembangan pengaturan mengenai pemerintahan desa.

\section{Politik Hukum Pemerintahan Desa Menurut Undang-Undang Nomor 32 Tahun 2004 tentang Pemerintahan Daerah}

Pada pasal 1 angka 12 UU Pemda 2004 desa didefnisikan sebagai berikut:

"Desa atau yang disebut dengan nama lain, selanjutnya disebut desa, adalah kesatuan masyarakat hukum yang memiliki batas-batas wilayah yang berwenang untuk mengatur dan mengurus kepentingan masyarakat setempat, berdasarkan asal-usul dan adat istiadat setempat yang diakui dan dihormati dalam sistem Pemerintahan Negara Kesatuan Republik Indonesia".

Kedudukan desa dinyatakan dalam Pasal 200 UU Pemda 2004 sebagai berikut:

1. Dalam pemerintahan Kabupaten/Kota dibentuk Pemerintahan Desa yang terdiri dari pemerintah desa dan badan permusyawaratan desa;

2. Pembentukan, penghapusan, dan/atau penggabungan Desa dengan memperhatikan asal usulnya atas prakarsa masyarakat;

3. Desa di kabupaten/kota secara bertahap dapat diubah atau disesuaikan statusnya menjadi kelurahan sesuai usul dan prakarsa pemerintah desa bersama badan permusyawaratan desa yang ditetapkan dengan Perda.

Kata 'dibentuk' pada ketentuan di atas dapat ditafsirkan bahwa pemerintah desa dibentuk oleh pemerintah kabupaten/kota. Oleh karena itu, berdasarkan ketentuan tersebut terlihat bahwa UU Pemda 2004 menghendaki desa menjadi entitas administrasi terendah yang keberlangsungannya sangat bergantung pada political will dari pemerintah atasannya. Kebijakan ini akan membuat desa menjadi sangat tergantung pada pemerintah atasannya dan membuka peluang yang sangat lebar akan adanya intervensi dari pemerintah atasan terhadap desa.

Selain itu, berdasarkan Pasal 200 ayat (3) UU Pemda 2004, dibuka kemungkinan bagi desa untuk berubah status menjadi kelurahan. Padahal antara desa dan kelurahan mengandung makna desentralisasi yang berbeda, yakni desentralisasi

\footnotetext{
11 Susi Dwi Harijanti, “Politik Hukum Keimigrasian Indonesia Menurut UU No. 9 Thn. 1992 dan UU No. 6 Thn. 2011 tentang Keimigrasian", Penelitian Unggulan Fakultas Hukum Universitas Padjadjaran, 2013, hlm. 7.

12 Imam Syaukani dan A. Ahsin Thohari, Dasar-Dasar Politik Hukum, Jakarta: Raja Grafindo Persada, 2008, hlm. 19.
} 
teritorial untuk desa dan desentralisasi administrasi (dekonsentrasi) untuk kelurahan. Ketentuan ini mengindikasikan bahwa undang-undang pemerintahan daerah tidak menghendaki untuk mempertahankan sistem pemerintahan desa di dalam kerangka sistem pemerintahan daerah dan lebih menghendaki untuk dilaksanakannya dekonsentrasi atau sentralisasi. ${ }^{14}$

Susunan pemerintahan desa menurut UU Pemda 2004 terdiri atas kepala desa dan perangkat desa. Perangkat desa terdiri atas sekretaris desa, pelaksana teknis lapangan, dan unsur kewilayahan. ${ }^{15}$ Sekretaris desa sendiri diisi oleh PNS yang memenuhi persyaratan. ${ }^{16}$ Sementara itu, kepala desa dipilih langsung oleh dan dari penduduk desa yang syarat dan tata cara pemilihannya diatur dengan peraturan daerah dengan mengacu kepada Peraturan Pemerintah Nomor 72 Tahun 2005 Tentang Desa (PP 72/2005). ${ }^{17}$ Di sisi lain, pada masyarakat hukum adat, pemilihan kepala desa dilakukan berdasarkan hukum adat setempat. ${ }^{18}$

Berdasarkan status sekretaris desa sebagai PNS sebagaimana dinyatakan di atas, dapat terlihat kehendak dari UU Pemda 2004 agar desa dapat diintervensi oleh pemerintah atasannya. Lebih jelas, Pasal 202 ayat (3) UU Pemda 2004 menyatakan bahwa sekretaris desa merupakan PNS. Pilihan kebijakan ini memperlihatkan adanya kecenderungan pemerintah untuk menempatkan desa sebagai satuan administrasi terendah yang berada di bawah kabupaten/kota. Selain itu, sebagaimana telah diutarakan sebelumnya, kebijakan ini pada akhirnya akan menimbulkan kecemburuan diantara perangkat desa lainnya, sehingga muncul tuntutan dari kepala-kepala desa untuk turut diangkat menjadi PNS.

Tuntutan kepala desa untuk diangkat menjadi PNS sebagaimana diuraikan di atas membuktikan bahwa kemandirian desa sudah semakin menghilang. Desa sudah tidak mampu lagi untuk menghidupi dirinya melalui sumber-sumber pendanaan yang asli. Jika tuntutan untuk memberikan status PNS kepada kepala desa diberikan, maka akan berpotensi untuk meruntuhkan tatanan asli desa yang tumbuh dan berkembang berdasarkan adat istiadat setempat dan berubah menjadi satuan administratif dari negara belaka.

Unsur pemerintahan desa lainnya adalah Badan Permusyawaratan Desa (BPD) yang berfungsi menetapkan peraturan desa bersama kepala desa dan menyalurkan aspirasi masyarakat. ${ }^{19}$ BPD beranggotakan wakil dari penduduk desa yang

\footnotetext{
13 Moh. Mahfud M.D., Membangun Politik Hukum, Menegakkan Konstitusi, Jakarta: LP3ES, 2006, hlm. 13.

14 Rahayu Prasetianingsih dan Inna Junaenah, "Perkembangan Pengaturan Pemerintahan Desa di Indonesia", Penelitian Fakultas Hukum Universitas Padjadjaran, 2008, hlm. 75.

15 Penjelasan Pasal 202 ayat (2) Undang-Undang Nomor 32 Tahun 2004 tentang Pemerintahan Daerah (UU Pemda 2004).

16 Pasal 202 ayat (3) UU Pemda 2004.

17 Kepala desa dipilih untuk masa jabatan selama 6 tahun dan dapat dipilih kembali hanya untuk 1 kali masa jabatan. Selain itu, kepala desa terpilih dilantik oleh bupati/walikota.

18 Pasal 203 ayat (3) UU Pemda 2004.

19 Pasal 209 UU Pemda 2004.
} 
bersangkutan yang ditetapkan dengan cara musyawarah dan mufakat. ${ }^{20}$ Selain itu, dibuka pula peluang bagi desa untuk dapat membentuk lembaga kemasyarakatan yang berfungsi untuk bermitra dengan pemerintah desa dalam rangka meningkatkan pemberdayaan masyarakat desa. ${ }^{21}$

Apabila dilihat berdasarkan karakter pengisian jabatan anggota BPD di atas, maka telah terjadi pergeseran sistem demokrasi yang dianut. ${ }^{22}$ Ketika anggota BPD tidak lagi dipilih oleh rakyat secara langsung, melainkan melalui musyawarah dan mufakat, berarti telah terjadi pergeseran sistem demokrasi perwakilan menuju sistem demokrasi deliberatif yang menghendaki adanya diskursus publik dalam pengisian anggota BPD. Namun demikian, pilihan tersebut berdampak pada persepsi masyarakat mengenai kedudukan BPD terhadap kepala desa. Anggota BPD yang tidak dipilih secara langsung oleh rakyat menjadikan kedudukannya seolah berada di bawah kepala desa yang dipilih secara langsung oleh rakyat. Pada kondisi yang demikian, BPD berpotensi kehilangan fungsi mendasar dalam sistem politik desa, yakni hilangnya fungsi pengawasan terhadap kepala desa. Di sisi lain, undangundang menghendaki kepala desa untuk bertanggungjawab secara langsung kepada bupati dan hanya memberikan keterangan pertanggungjawaban kepada BPD. ${ }^{23} \mathrm{Hal}$ ini mengindikasikan bahwa keterangan pertanggungjawaban kepada BPD hanya sebatas memenuhi kebutuhan formal belaka. ${ }^{24}$

Dari sisi kewenangan, UU Pemda 2004 desa diberikan kewenangan berupa:

1. Urusan pemerintahan yang sudah ada berdasarkan hak asal-usul;

2. Urusan pemerintahan yang menjadi kewenangan kabupaten/kota yang diserahkan pengaturannya kepada desa;

3. Tugas pembantuan dari pemerintah, pemerintah provinsi, dan/atau pemerintah kabupaten/kota; dan

4. Urusan pemerintahan lainnya yang oleh peraturan perundang-undangan diserahkan kepada desa.

Dari sisi keuangan desa, pengelolaan keuangan desa dilakukan oleh kepala desa yang dituangkan dalam bentuk peraturan desa tentang anggaran pendapatan dan belanja desa. ${ }^{25}$ Sumber-sumber pendapatan desa terdiri atas:

\footnotetext{
20 Pasal 210 ayat (1) UU Pemda 2004.

21 Pasal 211 ayat (2) UU Pemda 2004.

22 Pada masa UU Pemerintahan Desa, terdapat Lembaga Musyawarah Desa yang berkedudukan sebagai unsur pemerintah desa yang beranggotakan kepala-kepala dusun, pimpinan lembaga-lembaga kemasyarakatan, dan pemuka-pemuka masyarakat. Artinya keanggotaan Lembaga Musyawarah Desa yang ekuivalen dengan Badan Permusyawaratan Desa pada UU Pemda 2004 tidak ditentukan melalui mekanisme pemilihan. Dapat dilihat pada Pasal 3 dan Pasal 17 UU Pemerintahan Desa.

23 Angka 10 Penjelasan Umum UU Pemda 2004.

24 Rahayu Prasetianingsih dan Inna Junnaenah, Op. cit., hlm. 83.

${ }^{25}$ Keuangan desa adalah semua hak dan kewajiban desa yang dapat dinilai dengan uang, serta segala sesuatu baik berupa uang maupun berupa barang yang dapat dijadikan milik desa berhubung dengan pelaksanaan hak dan kewajiban yang menimbulkan pendapatan, belanja dan pengelolaan keuangan desa. Dapat dilihat pada Pasal 212 UU Pemda 2004
} 
1. Pendapatan asli desa;

2. Bagi hasil pajak daerah dan retribusi daerah kabupaten/kota;

3. Bagian dari dana perimbangan keuangan pusat dan daerah yang diterima oleh kabupaten/kota;

4. Bantuan dari pemerintah, pemerintah provinsi, dan pemerintah kabupaten/kota; dan

5. Hibah dan sumbangan dari pihak ketiga.

Dalam rangka meningkatkan pendapatan, desa dapat mendirikan badan usaha milik desa sesuai dengan kebutuhan dan potensi desa. ${ }^{26}$ Selain itu, desa juga dapat mengadakan kerja sama untuk kepentingan desa yang diatur dengan keputusan bersama dan dilaporkan kepada bupati. ${ }^{27}$ Berdasarkan ketentuan-ketentuan mengenai sumber-sumber keuangan desa di atas, terlihat bahwa undang-undang pemerintahan daerah menghendaki desa dapat otonom dari sisi sumber pendapatan. Hal ini terlihat dari dibukanya dua keran sumber pendanaan, yakni melalui aliran dana dari satuan pemerintahan yang lebih tinggi dan melalui potensipotensi desa baik berupa potensi pendanaan yang berasal dari pendapatan asli desa ataupun melalui badan usaha milik desa serta model kerjasama desa.

Berdasarkan uraian di atas, maka posisi desa menjadi ambivalen dan tidak jelas. Di satu sisi, UU Pemda 2004 menghendaki desa untuk tetap hidup sebagai sebuah bentuk otonomi asli melalui kemandirian pada sisi pendanaan. Di sisi lain, penentuan status perangkat desa yang mengarah pada dekonsentrasi dan adanya norma yang memungkinkan desa berubah menjadi kelurahan mencerminkan adanya kehendak untuk membuat desa menjadi satuan pemerintahan administratif di bawah kecamatan.

\section{Politik Hukum Pemerintahan Desa Menurut Undang-Undang Nomor 6 Tahun 2014 tentang Desa}

UU Desa membagi desa menjadi dua jenis, yakni 'desa' dan 'desa adat'. Pembagian tersebut dinyatakan pada Pasal 1 angka 1 UU Desa sebagai berikut:

"Desa adalah desa dan desa adat atau yang disebut dengan nama lain, selanjutnya disebut desa, adalah kesatuan masyarakat hukum yang memiliki batas wilayah yang berwenang untuk mengatur dan mengurus urusan pemerintahan, kepentingan masyarakat setempat berdasarkan prakarsa masyarakat, hak asal-usul, dan/atau hak tradisional yang diakui dan dihormati dalam sistem pemerintahan Negara Kesatuan Republik Indonesia".

Pada Pasal 5 UU Desa, kedudukan desa dinyatakan berada di wilayah kabupaten/kota. Secara lebih lanjut pasal tersebut juga menyatakan sebagai

\footnotetext{
26 Pasal 213 UU Pemda 2004.

27 Pasal 213 UU Pemda 2004.
} 
berikut: "Desa berkedudukan di wilayah Kabupaten/Kota". Berdasarkan ketentuan ini, terlihat pergeseran politik hukum mengenai kedudukan desa. Pada undangundang terdahulu, desa dinyatakan sebagai bentukan kabupaten/kota, namun pada UU Desa, desa tidak dibentuk oleh kabupaten/kota, melainkan hanya dinyatakan berkedudukan baik di kabupaten/kota. Maka dari itu, kedudukan desa pada undang-undang yang baru merupakan bentuk pengakuan negara terhadap desa.

Meskipun begitu, ketentuan mengenai pembentukan desa tetap diatur dalam UU Desa. ${ }^{28}$ Pada Pasal 7 UU Desa dinyatakan bahwa pemerintah, pemerintah provinsi, dan pemerintah kabupaten/kota dapat melakukan penataan daerah dengan cara:

1. Pembentukan;

2. Penghapusan;

3. Penggabungan;

4. Perubahan status; dan

5. Penetapan desa.

Berdasarkan ketentuan di atas, maka pembentukan desa hanya dapat dimaknai sebagai bentuk penataan desa yang hanya dapat dilakukan dalam kerangka evaluasi tingkat perkembangan pemerintahan desa dan ditujukan untuk mewujudkan efektifitas, mempercepat peningkatan kesejahteraan, mempercepat peningkatan kualitas layanan publik, meningkatkan tata kelola pemerintahan desa, dan meningkatkan daya saing desa. Bahkan dalam Pasal 9 UU Desa dinyatakan bahwa desa dapat dihapus atas dasar kepentingan nasional yang strategis. Oleh karena itu, meskipun politik hukum pengakuan atas desa lebih terlihat, namun kedudukan dan keberlangsungan desa pada undang-undang ini masih sangat tergantung pada political will satuan pemerintahanan atasan desa.

Selain itu, berdasarkan Pasal 11 UU Desa maka kemungkinan bgai desa untuk berubah status menjadi kelurahan masih tetap dibuka. ${ }^{29}$ Meskipun gagasan untuk berubah menjadi kelurahan harus datang dari prakarsa masyarakat desa, ${ }^{30}$ namun dibukanya peluang ini mengindikasikan bahwa pemerintah tidak menghendaki untuk mempertahankan sistem pemerintahan desa di dalam kerangka sistem pemerintahan daerah, dan lebih menghendaki untuk dilaksanakannya dekonsentrasi dan sentralisasi.

Adapun mengenai kewenangan desa dinyatakan dalam Pasal 19 UU Desa adalah sebagai berikut:

1. Kewenangan berdasarkan hak asal-usul;

2. Kewenangan lokal berskala desa;

\footnotetext{
28 Pasal 7 ayat (4) Undang-Undang Nomor 6 Tahun 2014 tentang Desa (UU Desa).

29 Pasal 11 UU Desa.

30 Pasal 11 ayat (1) UU Desa.
} 
3. Kewenangan yang ditugaskan oleh pemerintah, pemerintah daerah provinsi, atau pemerintah kabupaten/kota; dan

4. Kewenangan lain yang ditugaskan oleh Pemerintah, Pemerintah Daerah Provinsi, atau Pemerintah Kabupaten/Kota sesuai dengan ketentuan peraturan perundang-undangan.

Dari sisi kewenangan sebagaimana disebutkan di atas, terlihat perkembangan arah politik hukum mengenai kewenangan desa menjadi lebih jelas memperlihatkan otonomi desa. Misalnya, pada Pasal 19 UU Desa dinyatakan bahwa desa memiliki kewenangan berdasarkan hak asal-usul dan kewenangan lokal berskala desa. Ketentuan mengenai kewenangan berdasarkan hak asal-usul memang dapat dijumpai dalam undang-undang terdahulu, tetapi kewenangan lokal berskala desa merupakan kewenangan baru yang memperlihatkan arah politik hukum pemerintahan desa menuju otonomi asli. ${ }^{31}$

Susunan pemerintahan desa menurut UU Desa terdiri atas kepala desa ${ }^{32}$ dan perangkat desa. Perangkat desa terdiri atas sekretaris desa, pelaksana kewilayahan, dan pelaksana teknis. ${ }^{33}$ Ketentuan ini tidak berbeda dengan UU Pemda 2004 namun tidak lagi ditemukan norma yang memberikan status PNS bagi perangkat desa tertentu seperti undang-undang sebelumnya yang menyatakan bahwa sekretaris desa adalah PNS. Perangkat desa diangkat oleh kepala desa setelah dikonsultasikan dengan camat atas nama bupati/walikota. Dalam melaksanakan tugas dan wewenangnya, perangkat desa bertanggungjawab kepada kepala desa. ${ }^{34}$ Begitu juga dengan mekanisme pemberhentian bagi perangkat desa, yakni melalui penetapan kepala desa setelah dikonsultasikan dengan camat atas nama bupati/walikota. ${ }^{35}$ Sementara itu, kepala desa dipilih langsung oleh dan dari penduduk desa. ${ }^{36}$ UU Desa menghendaki pemilihan kepala desa dilakukan secara serentak di seluruh wilayah kabupaten/kota. ${ }^{37}$

Berdasarkan ketentuan di atas, terlihat upaya dari pemerintah untuk mengembalikan hakikat desa sebagai pemangku otonomi asli. Upaya tersebut dapat dilakukan misalnya dengan tidak lagi memberikan status PNS bagi sekretaris desa, sehingga desa hendak didudukan sebagai entitas desentralisasi dan bukan dekonsentrasi. Meskipun begitu, perangkat desa berhak untuk mendapatkan penghasilan dan tunjangan-tunjangan lainnya sebagaimana diatur dalam Pasal 66

\footnotetext{
31 Otonomi asli memiliki makna kewenangan pemerintahan desa dalam mengatur dan mengurus kepentingan masyarakat setempat didasarkan pada hak asal-usul dan nilai-nilai sosial yang ada pada masyarakat setempat. Namun, harus diselenggarakan dalam perspektif administrasi pemerintahan modern.

32 Pasal 26 UU Desa.

${ }^{33}$ Pasal 58 UU Desa.

${ }^{34}$ Pasal 49 UU Desa.

35 Pasal 52 ayat (3) UU Desa.

36 Pasal 34 UU Desa.

37 Pasal 31 UU Desa.
} 
UU Desa sebagai berikut:

1. Kepala desa dan perangkat desa memperoleh penghasilan tetap setiap bulan;

2. Penghasilan tetap kepala desa dan perangkat desa sebagaimana dimaksud pada ayat (1) bersumber dari dana perimbangan dalam Anggaran Pendapatan dan Belanja Negara yang diterima oleh Kabupaten/Kota dan ditetapkan dalam Anggaran Pendapatan dan Belanja Daerah Kabupaten/Kota;

3. Selain penghasilan tetap sebagaimana dimaksud pada ayat (1), kepala desa dan perangkat desa menerima tunjangan yang bersumber dari Anggaran Pendapatan dan Belanja Desa; dan

4. Selain penghasilan tetap sebagaimana dimaksud pada ayat (1), kepala desa dan perangkat desa memperoleh jaminan kesehatan dan dapat memperoleh penerimaan lainnya yang sah.

Ketentuan mengenai gaji dan tunjangan tetap bagi kepala desa dan perangkat desa tersebut sesungguhnya berpotensi menciptakan ketergantungan desa pada keuangan dari satuan pemerintahan yang lebih tinggi. Namun demikian, ketentuan tersebut dapat pula dimaknai sebagai upaya pemerintah untuk mempertahankan eksistensi desa mengingat sumber-sumber pendapatan asli desa sempat runtuh akibat politik hukum penyeragaman pada UU Pemerintahan Desa.

Unsur pemerintahan desa lainnya adalah BPD yang berfungsi menetapkan peraturan desa bersama kepala desa dan menyalurkan aspirasi masyarakat. ${ }^{38}$ BPD beranggotakan wakil dari penduduk desa yang bersangkutan yang dipilih secara demokratis. ${ }^{39}$ Pengisian jabatan anggota BPD tersebut berbeda dengan pemilihan kepala desa yang dinyatakan secara eksplisit untuk dilakukan pemilihan secara langsung oleh penduduk desa. ${ }^{40}$ Ketentuan mengenai pengisian jabatan anggota BPD melalui mekanisme yang demokratis memperlihatkan politik hukum pembentuk undang-undang yang memberikan keleluasaan kepada masing-masing desa untuk menentukan sendiri mekanisme demokratis yang dikehendaki dalam memilih anggota BPD.

Seperti pada undang-undang terdahulu, pengelolaan keuangan desa dilakukan oleh kepala desa yang dituangkan dalam bentuk peraturan desa tentang anggaran pendapatan dan belanja desa. ${ }^{41}$ Undang-Undang juga memberikan keleluasaan kepada kepala desa untuk menguasakan sebagian kekuasaannya kepada perangkat desa. ${ }^{42}$ Adapun sumber-sumber pendapatan desa terdiri atas:

\footnotetext{
38 Pasal 55 UU Desa.

39 Pasal 56 UU Desa.

40 Pasal 56 ayat (3) UU Desa.

41 Keuangan desa adalah semua hak dan kewajiban desa yang dapat dinilai dengan uang, serta segala sesuatu baik berupa uang maupun berupa barang yang dapat dijadikan milik desa berhubung dengan pelaksanaan hak dan kewajiban yang menimbulkan pendapatan, belanja dan pengelolaan keuangan desa. Dapat dilihat Pasal 73, 74, dan 75 UU Desa.

42 Pasal 75 ayat (2) UU Desa.
} 
1. Pendapatan asli desa terdiri atas hasil usaha, hasil aset, swadaya dan partisipasi, gotong royong, dan lain-lain pendapatan asli desa;

2. Alokasi APBN;

3. Bagian dari hasil pajak daerah dan retribusi daerah kabupaten/kota;

4. Alokasi dana desa yang merupakan bagian dari dana perimbangan yang diterima kabupaten/kota;

5. Bantuan keuangan dari Anggaran Pendapatan dan Belanja Daerah (APBD) provinsi dan APBD kabupaten/kota;

6. Hibah dan sumbangan yang tidak mengikat dari pihak ketiga; dan

7. Lain-lain pendapatan desa yang sah.

Berdasarkan sumber-sumber pendanaan sebagaimana tercantum di atas, terlihat bahwa desa diberikan ruang yang lebih besaroleh UU Desa untuk mendapatkan sumber-sumber pendapatan yang bersifat pasti. Penambahan ruang tersebut terlihat dari adanya pengaturan mengenai alokasi dana desa yang merupakan bagian dari dana perimbangan yang diterima kabupaten/kota dan alokasi dana dari APBN. Berdasarkan ketentuan di atas, terlihat bahwa undangundang menghendaki adanya keseimbangan dalam otonomi desa dalam hal sumber-sumber pendanaan. Keseimbangan yang dimaksud bahwa pendanaan desa sebagai daerah otonom harus didapatkan dari sumber-sumber pendapatan asli. Namun sebagai bagian dari sistem desentralisasi dalam kerangka negara kesatuan, maka pendanaan dari satuan pemerintahan yang lebih tinggi menjadi sebuah konsekuensi desentralisasi. Terlebih lagi apabila desa, berdasarkan ketentuan di atas, dapat melaksanakan fungsi-fungsi pemerintahan yang dibebankan kepadanya.

\section{Prospek dan Tantangan Penyelenggaraan Pemerintahan Desa di Masa Depan}

Sebagaimana telah diuraikan pada bagian sebelumnya, bahwa politik hukum UU Desa adalah mengembalikan pengelolaan desa pada konsep otonomi asli melalui pengukuhan pengakuan atas kedudukan desa, pemberian kewenangan lokal berskala desa, pemberian status dan kedudukan perangkat desa yang bukan sebagai aparat pemerintah, serta pemberian pendanaan bagi desa melalui APBN dan dana perimbangan dalam bentuk alokasi dana desa.

Dalam konteks implementasi, UU Desa akan menghadapi berbagai tantangan terkait kesiapan desa dalam menjalankan kewenangan-kewenangannya, hingga persepsi pemerintah daerah terhadap kedudukan desa. Kegagalan pemerintah daerah dan desa dalam mengelola tantangan tersebut akan mengakibatkan politik hukum pemerintahan desa sebagai pemangku otonomi asli tidak dapat terwujud.

UU Desa tidak lagi menempatkan desa sebagai subordinat pemerintah daerah. Dengan demikian, undang-undang menempatkan desa sebagai sebuah entitas 
hukum yang diakui sebagai mitra pemerintah pusat dan daerah dalam mewujudkan kesejahteraan bagi masyarakat desa. ${ }^{43}$ Pada kondisi seperti ini, persepsi aparat pemerintah dan pemerintah daerah terhadap desa harus dapat menunjang kedudukan desa sebagai entitas hukum yang otonom dan bukan sebagai sebuah entitas administratif. Keberadaan desa harus dapat dipersepsikan sebagai sebuah perwujudan partisipasi masyarakat dalam rangka menciptakan kesejahteraan. Artinya, aparat pemerintah pusat dan daerah harus mampu mempersepsikan desa sebagai bagian integral dari pemerintah daerah.

Bentuk kemitraan antara pemerintah pusat dan daerah dengan pemerintah desa dapat terlihat pada Pasal 112-115 UU Desa yang mengatur mengenai pembinaan dan pengawasan kepada pemerintah desa. ${ }^{44}$ Bentuk-bentuk pembinaan dan pengawasan yang dimaksud pada pasal-pasal tersebut dapat berupa pedoman dan petunjuk pelaksanaan pemerintahan desa hingga fasilitasi desa dalam hal pembentukan Badan Usaha Milik Desa (BUMDes). Pedoman-pedoman tersebut dapat berpotensi mengikis otonomi desa apabila pedoman-pedoman tersebut dibentuk dengan sangat rigid. Oleh karena itu, pembentukan pedoman-pedoman dalam konteks pembinaan dan pengawasan harus dilakukan dengan menyertakan desa sebagai perwujudan persepsi bahwa desa sebagai mitra pemerintah dan bukan satuan administratif yang subordinat.

Dari sisi keuangan, UU Desa memberikan sumber-sumber keuangan yang lebih pasti bagi desa melalui alokasi dana desa dan APBN. Ketentuan mengenai alokasi dana desa diatur dalam Peraturan Pemerintah Nomor 43 Tahun 2014 tentang Peraturan Pelaksana Undang-Undang Nomor 6 Tahun 2014 tentang Desa (PP 43/2014) yang menyatakan bahwa alokasi dana desa merupakan alokasi dana bagi desa yang berasal dari dana perimbangan pusat kepada daerah yang besarnya paling sedikit 10\% dari dana perimbangan yang diterima pemerintah daerah setelah dikurangi dana alokasi khusus. ${ }^{45}$ Sementara itu, besaran nominal alokasi dana APBN akan dianggarkan setiap tahun oleh pemerintah. ${ }^{46}$ Ketentuan mengenai alokasi dana APBN diatur dalam Peraturan Pemerintah Nomor 60 Tahun 2014 tentang Dana Desa Yang Bersumber Dari Anggaran Pendapatan Dan Belanja Negara (PP 60/2014). Besaran alokasi dana APBN ini akan dihitung berdasarkan jumlah desa dengan

${ }^{43}$ Lihat uraian di atas mengenai kedudukan desa dalam kerangka pemerintahan daerah. Dapat dilihat juga Pasal 5 UU Desa.

${ }^{44}$ Bentuk-bentuk pedoman yang dimaksud dapat berasal baik dari pemerintah pusat maupun pemerintah daerah yang diantaranya dapat memberikan arahan mengenai pedoman dan standar pelaksanaan penyelenggaraan pemerintahan desa, pedoman penyusunan perencanaan pembangunan partisipatif, pedoman standar jabatan bagi perangkat desa, dan lain-lain. Dapat dilihat pada Pasal 112-115 UU Desa.

45 Pasal 96 Peraturan Pemerintah Nomor 43 Tahun 2014 tentang Peraturan Pelaksana Undang-Undang Nomor 6 Tahun 2014 tentang Desa (PP 43/2014).

46 Pasal 3 Peraturan Pemerintah Nomor 60 Tahun 2014 tentang Dana Desa Yang Bersumber Dari Anggaran Pendapatan Dan Belanja Negara (PP 60/2014). 
memperhatikan jumlah penduduk, angka kemiskinan, luas wilayah, dan tingkat kesulitan geografis. ${ }^{47}$ Meskipun secara besaran nominal, dua sumber pendapatan desa ini tidaklah pasti, tetapi akan secara rutin didapatkan oleh desa melalui APBD dan APBN.

Meskipun UU Desa telah mengandung jaminan sumber-sumber keuangan bagi desa, tetapi terdapat beberapa ketentuan di dalam undang-undang tersebut yang berpotensi mengganggu efektivitas jalannya pemerintahan desa. Sebagai contoh, ketentuan yang mengatur mengenai mekanisme pelaporan dan pertanggungjawaban keuangan yang tidak efisien. UU Desa memang tidak secara eksplisit mengatur mengenai tata cara pelaporan keuangan bagi desa. Tata cara pelaporan keuangan bagi desa diatur secara jelas di dalam PP 43/2014. Dalam Pasal 103 dan 104 PP 43/2014 dinyatakan bahwa Kepala Desa berkewajiban untuk: ${ }^{48}$

1. menyampaikan realisasi pelaksanaan Anggaran Pendapatan Belanja Desa (APBDes) kepada bupati/walikota setiap semester tahun berjalan (laporan semesteran); dan

2. Menyampaikan laporan pertanggungjawaban realisasi pelaksanaan APBDesa kepada bupati/walikota setiap akhir tahun anggaran (laporan tahunan).

Sementara itu, berdasarkan Pasal 24 PP 60/2014 dinyatakan bahwa kepala desa harus menyampaikan laporan realisasi penggunaan dana desa kepada bupati/walikota setiap semester. ${ }^{49}$ Berdasarkan ketentuan-ketentuan mengenai kewajiban pelaporan dana di atas, terlihat bahwa desa dibebani kewajiban administrasi yang cukup banyak, baik yang bersifat integral dalam bentuk laporan penggunaan APBDes setiap semester dan akhir tahun, serta laporan realisasi penggunaan dana desa yang khusus bersumber dari APBN setiap semester. Kondisi ini akan mengakibatkan desa menjadi lebih sibuk untuk memenuhi kewajibankewajiban administrasinya ketimbang melakukan kegiatan-kegiatan yang produktif dalam rangka pengembangan potensi desa. Keadaan ini mengakibatkan politik hukum pemerintahan desa menjadi ambivalen dan tidak jelas karena di satu sisi menghendaki desa menjadi sebuah entitas yang otonom, namun di sisi lain desa dibebankan pada berbagai kewajiban administratif.

Kewajiban-kewajiban administrasi yang dibebankan kepada desa tersebut cenderung mengakibatkan pemerintah desa menjadi lebih birokratik. Keadaan ini memperlihatkan pula adanya kecenderungan untuk memposisikan desa sebagai satuan pemerintahan yang bersifat administratif. Hal ini diperkuat ketika desa dapat pula dibebani tugas-tugas yang merupakan pelimpahan tugas dari satuan pemerintahan yang lebih tinggi, baik dari pemerintah kabupaten/kota ataupun

\footnotetext{
47 Pasal 5 ayat (2) PP 60/2014.

48 Lihat Pasal 103 dan Pasal 104 PP 43/2014.

49 Lihat Pasal 24 PP 60/2014.
} 
tugas dari pemerintah provinsi. ${ }^{50}$ Beban administrasi dan pelimpahan tugas kepada desa sebagaimana diuraikan di atas, merefleksikan adanya birokratisasi pemerintahan desa. Kondisi ini jelas tidak sejalan dengan kehendak untuk menghidupkan kembali desa sebagai satuan pemerintahan dengan otonomi asli.

Berdasarkan uraian mengenai alokasi dana desa dan alokasi dana APBN sebagai salah satu sumber pendanaan bagi desa, terdapat beberapa hal yang perlu untuk diperhatikan, yakni: Pertama, kemampuan desa dalam melakukan perencanaan keuangan desa. Dalam praktik, perencanan anggaran desa melalui musyawarah perencanaan pembangunan desa (musrenbangdes) masih berorientasi pada penganggaran belanja rutin penyelenggaraan pemerintahan desa dan belum berorientasi pada pengembangan potensi desa menuju kemandirian. ${ }^{51}$ Kedua, kemampuan perangkat desa dalam melakukan pengelolaan dan pelaporan keuangan desa. Masih minimnya kompetensi sumber daya manusia (SDM) di desa berpotensi mengakibatkan implementasi penggunaan anggaran tidak sejalan dengan perencanaan, terlebih mekanisme pencairan alokasi dana desa dan alokasi dana APBN dikucurkan secara bertahap dengan jumlah yang bervariasi.

\section{Penutup}

Berdasarkan uraian di atas, maka dapat disimpulkan bahwa pada UU Pemda 2004, kedudukan desa berada pada posisi yang ambivalen dan tidak jelas. Di satu sisi, politik hukum UU Pemda 2004 menghendaki desa untuk tetap hidup sebagai sebuah bentuk otonomi asli melalui kemandirian pada sisi pendanaan. Di sisi lain, norma-norma undang-undang menghendaki bahwa penentuan status perangkat desa mengarah pada dekonsentrasi. Selain itu, terdapat norma yang memungkinkan desa berubah menjadi kelurahan. Norma tersebut mencerminkan adanya kehendak untuk membuat desa menjadi satuan pemerintahan administratif dibawah kecamatan.

Sementara itu berdasarkan UU Desa, terlihat bahwa politik hukum pemerintahan desa mengarah pada otonomi desa yang menghendaki desa dijalankan dengan prinsip otonomi asli. Kehendak untuk menghidupkan otonomi asli di desa terlihat dari peniadaan unsur PNS pada perangkat desa. Selain itu apabila dilihat dari aspek pendanaan, undang-undang ini menghendaki adanya keseimbangan sumber pendanaan, baik sumber-sumber pendanaan yang bersifat asli maupun sumber-sumber pendanaan yang merupakan konsekuensi desentralisasi. Meskipun begitu, sumber-sumber keuangan tersebut melahirkan beban tanggung jawab pelaporan yang cukup banyak bagi desa yang pada akhirnya

\footnotetext{
50 Lihat Pasal 19 huruf d UU Desa.

51 Farid S, Zuhri, "Tantangan Implementasi UU Desa”, http://www.gapuradesa.co.id/artikel-tantanganimplementasi-uu-desa-1/2 diakses 9 Juli 2014.
} 
menjadi beban administratif bagi desa. Lebih lanjut lagi pada rezim undang-undang ini, desa dapat pula dibebani tugas yang diberikan oleh satuan pemerintahan yang lebih tinggi. Keadaan ini ambivalen terhadap kehendak menjadikan desa sebagai entitas pemerintahan dengan otonomi asli dan cenderung menjadikan desa lebih bernuansa birokratik.

Perkembangan politik hukum pemerintahan desa pada akhirnya mengharuskan otonomi desa untuk ditafsirkan dengan makna bahwa desa bukan hanya sebagai entitas administratif (administrative entity), tetapi sebagai entitas hukum (legal entity) yang berarti harus dihargai, diistimewakan, dilindungi dalam struktur pemerintahan di Indonesia. Karena itu, makna pemerintahan desa sebagai bagian integral dari pemerintahan daerah bukan dimaknai hanya sebagai satuan administrasi, melainkan dimaknai sebagai wujud partisipasi sehingga pemerintahan desa mempunyai hak berpartisipasi dalam jalannya pemerintahan daerah, mengingat adanya kesamaan kepentingan dalam bersama-sama mensejahterakan masyarakat.

\section{Daftar Pustaka}

\section{Buku}

Bayu Surianingrat, Pemerintahan Administrasi Desa dan Kelurahan, Rineka Cipta, Jakarta, 1992.

Imam Syaukani dan A. Ahsin Thohari, Dasar - Dasar Politik Hukum, Raja Grafindo Persada, Jakarta, 2008.

Moh. Mahfud M.D., Membangun Politik Hukum, Menegakkan Konstitusi, LP3ES, Jakarta, 2006.

Yudi Latif, Negara Paripurna, Gramedia Pustaka Utama, Jakarta, 2011.

Soetardjo Kartohadikoesoemo, Desa, Sumur Bandung, Yogyakarta, 1953.

\section{Dokumen Lainnya}

Farid S, Zuhri, "Tantangan Implementasi UU Desa”, http://www.gapuradesa.co.id/ artikel-tantangan-implementasi-uu-desa-1/, 2014.

Koran Sindo, "Perangkat Desa Kembali Tuntut Dijadikan PNS", 2012.

Rahayu Prasetianingsih dan Inna Junaenah, Perkembangan Pengaturan Pemerintahan Desa di Indonesia, Penelitian Fakultas Hukum Universitas Padjadjaran, 2008.

Rega Felix, "Kedudukan Perangkat Desa Dalam Sistem Pemerintahan Desa di Indonesia", Skripsi Fakultas Hukum Universitas Padjadjaran, 2013.

Susi Dwi Harijanti, "Politik Hukum Keimigrasian Indonesia Menurut UU No. 9 Thn. 1992 dan UU No. 6 Thn. 2011 tentang Keimigrasian", Penelitian Unggulan Fakultas Hukum Universitas Padjadjaran, 2013. 


\section{Dokumen Hukum}

Undang-Undang Nomor 5 Tahun 1974 tentang Pemerintahan Daerah.

Undang-Undang Nomor 5 Tahun 1979 tentang Pemerintahan Desa.

Undang-Undang Nomor 32 Tahun 2004 tentang Pemerintahan Daerah.

Undang-Undang Nomor 6 Tahun 2014 tentang Desa.

Peraturan Pemerintah Nomor 43 Tahun 2014 tentang Peraturan Pelaksana UndangUndang Nomor 6 Tahun 2014 tentang Desa.

Peraturan Pemerintah Nomor 60 Tahun 2014 tentang Dana Desa Yang Bersumber Dari Anggaran Pendapatan dan Belanja Negara. 